\title{
Testing: A Systemic Functional View of High Stakes Test Preparation Materials*
}

\author{
Las pruebas de lenguaje desde una perspectiva sistémica \\ funcional de la preparación de materiales
}

\author{
Joshua Schulze \\ Graduate School of Education \\ University of Massachusetts, Boston \\ E-mail: jschulze@educ.umass.edu
}

Abstract

Educators of English language learners (ELLs) frequently use test preparation materials to help ELLs prepare for high stakes language exams. This study uses tools of systemic functional linguistics (SFL) to examine how academic language is used to construct meaning within these test preparation materials. While the test preparation materials and available test excerpts contain a range of genres, this study focuses particularly on informational texts with scientific topics, designed for upper elementary students. The results highlight pedagogical advantages of using SFL to develop genre awareness in ELLs by attending to the linguistic features evident in the genre.

Key words: systemic functional linguistics, genre analysis, English language learners

\section{Resumen}

Los docentes de inglés usan con frecuencia materiales de preparación para ayudarles a los aprendices a tomar exámenes estandarizados que midan su conocimiento en esta lengua. Este estudio usa herramientas de la lingüística sistémica funcional (SFL), para examinar cómo el lenguaje académico es usado para construir significado en los materiales de preparación para las pruebas. Aunque los materiales de preparación de pruebas y otros resúmenes disponibles contienen varios géneros textuales este estudio particularmente se enfoque en los textos informativos con temas científicos diseñados para estudiantes de los grados más altos de educación primaria. Los resultados muestran ventajas pedagógicas al usar lingüística sistémica funcional para desarrollar la conciencia sobre el uso de los diferentes géneros textuales fijándose en las características lingüísticas evidentes en cada género.

Palabras Claves: lingüística sistémica funcional, análisis de géneros textuales, estudiantes de inglés como segunda lengua

\section{Introduction}

U.S. federal mandates require public school districts to assess the progress of all enrolled students, including English language learners (ELLs) (US Department of Education website, 2007). In most states, this assessment takes the form of a standardized test. These tests are considered "high-stakes" in nature (Lipman, 2004) because the results can affect whether students meet the requirements for promotion and whether their school demonstrates adequate yearly progress (AYP). Schools not demonstrating AYP face punitive financial measures such as decreased federal funding and loss of institutional control (Kohn, 2000). School districts with a

* Received 28-10-08/ Accepted 18-05-09 
large number of ELLs face a particular challenge in ensuring that all students learn English and demonstrate proficiency on these exams.

Massachusetts and Texas are two such US states meeting this challenge. To do so, they have adopted curricular materials specifically designed to prepare students for the English language arts portions of their exams. In Massachusetts many districts prepare students for the Massachusetts Comprehensive Assessment System (MCAS) by using a text entitled Review, Practice and Mastery of English (Pearson Learning, 2007). In Texas, teachers prepare students for the Texas Assessment of Knowledge and Skills (TAKS) using the TAKS Study Guide (Texas Educational Agency, 2007).

The effectiveness of test preparation materials such as these has yet to be determined. However, researchers of children's academic literacy practices have found that not all students enter school equally prepared to engage with the academic language typically found on these tests (Brice-Health, 1982; Schleppegrell, 2004). Schleppegrell (2004) notes that knowledge of "schooled" ways of language use remains unequally distributed in society. ELLs, even those who have mastered social English, face the difficulty of transferring the language they speak at home and in their communities to the academic English found in the context of the school setting, in particular the language found on tests and test preparation materials. In this case, language tests constitute a context in which meaning is made and therefore must be studied.

With that in mind, this research uses the tools of systemic functional linguistics (SFL) to examine how academic language is used to construct meaning within these test preparation materials. While the test preparation materials and available test excerpts contain a range of genres, this study focuses particularly on informational texts with scientific topics.
Specifically, the analysis focuses on informational texts designed for upper elementary students. Passages 1-3 come from $4^{\text {th }}$ grade MCAS preparation materials, including a released test available for student practice. The first passage is entitled "Tornados" (pp. 15-16) and serves to describe the nature of this phenomenon. The second is entitled "Things That Fall From the Sky" (pp. 60) and describes asteroids. The third passage, entitled "Digging Dirt", describes, as its title suggest, dirt and its uses and usefulness to humans.

Passages 4-6 represent informational texts taken from the TKAS preparation materials and released tests available for public consumption (www.tea.state.tx.us.student.assessment/ resource/guides). The excerpts "Mystery of the Moving Rocks," "Planet Facts," and "Emperors of the Antartic" all come from the fourth and fifth grade reading test guides.

The reasons for focusing on informational texts are many. Previous research has found that informational texts, particularly those addressing scientific topics, construct meaning through language in particular ways and these ways may pose challenges for ELLs (Fang, 2004, 2006; Gebhard, Habana-Hafner, and Wright, 2004; Halliday and Matthiessen, 2004; Lemke, 1990; Schleppegrell, 2004, 2006,2007; Schleppegrell, Achugar and Oteiza, 2004; Schleppegrell and Go, 2007). Fang (2004, 2006), for example, observes that the language found in science texts typically uses "specialized grammar" that "renders scientific writing particularly dense, technical and abstract" (Fang, 2006, pp. 337).

The following passage from a Texas Assessment of Knowledge and Skills (TAKS), examples of which are analyzed in this study, exemplifies this abstract and dense language use typical of informational texts with scientific topics.

Increases in Earth's temperatures, called global warming, could cause large amounts 
of ice to break up and float into the ocean. Scientists fear that this drastic change in the environment could destroy many of the emperor's nesting areas. This would cause the number of emperor penguins to decrease.

Confronted with academic texts such as this one, ELLs not only face the challenge of translating the texts from their first language to English, but also of learning to make sense of more formal and abstract linguistic structures than those typically encountered within their own primary discourse community (Gee, 1990). To comprehend passages like the one above, ELLs have to construct meaning by unpacking the text at the clause level. In doing so, they encounter a number of content specific lexical terms that they have to translate such as "global warming," "environment," and "nesting areas." ELLs further encounter a level of grammatical metaphor represented by the text's use of nominalizations such as "increases" and "changes."

Unpacking these grammatically intricate forms presents a challenge for ELLs as they try to figure out who is doing what to whom in the clause especially since "increases" and "changes," in contrast to "penguins' or "scientists," do not represent easily generalizable participants typical of "commonsense language" found in home discourse practices (Derewianka, 1990; Schleppegrell, 2004).

\section{Theoretical Framework -Systemic Functional Linguistics}

To uncover how language is used to construct meaning within informational texts as found in the context of test preparation materials, a genre analysis using systemic functional linguistics (SFL) was conducted. Drawing on the work of Halliday $(1978,2004)$ language researchers have promoted this form of analysis as a way of looking closely at how grammar constructs meaning through the systematic presentation of choices that language users have to achieve different goals in academic settings and outside of school.

According to Halliday, three existing metafunctions give meaning to language. They are the ideational, interpersonal, and textual. The ideational represents "what is going in the world" and "who does what to whom, and where" (Kress, et. al., 2001, p.13). The interpersonal concerns itself with personal interaction. The textual concerns itself with the way ideas are held together and presented across a text. The three metafunctions work together to create meaning, and while they are inseparable, linguistic analysis that calls attention to certain indicators of each of the metafunctions deepens an understanding of their individual contributions.

When analyzing the contribution of the ideational metafunction to meaning construction, SFL analysts look primarily at processes and participants. Processes constitute the principal focal element of the clause because the clause is essentially about the action performed by the clause participants (Thompson, 2004). These processes typically fit into one of six categories: material, mental, relational, behavioral, verbal, and existential. SFL term those who are acting or being acted upon the actors or goals respectively and the terms for these actors and goals vary according to the process used within the clause. For instance, actors associated with mental processes are termed sensers and the goal being acted upon is termed the phenomenon. The textual analysis that follows revealed that material, relational and mental processes comprised the majority of processes used within test preparation materials, and these related terms will be employed.

\section{Methodology}

To analyze the ideational metafunction's contribution to meaning construction within the 
texts, the following research questions guided my study:

1. What does a genre analysis using SFL reveal about the language of informational texts with scientific topics in materials designed to prepare ELLs for high-stakes language arts assessments?

2. What pedagogical implications for ESL literacy instruction result from a close analysis of the role of the ideational metafunction in meaning construction?

\section{Data Analysis}

The first step in data analysis for this study included identifying informational texts with scientific topics from the collected sources. Next, a chart consisting of six columns each labeled with one of the six processes (material, mental, relational, behavioral, verbal and existential) was created. Under each process column, an additional column with the corresponding participant was created. For example, under the mental processes column, sensers and phenomenon were placed and under the material processes column, Actors and goals. (See appendix 1 for sample data analysis sheet).

Once all the processes and participants were categorized, the percentage of each type of process appearing in the text was calculated to discover which processes appeared most frequently. Then the number of processes in all texts was tabulated to see which processes were most frequently employed across the genre sample as a whole.

\section{Findings}

During this section of the study, examples of the processes as they appeared in the six sample texts will be identified and their contributions to meaning construction analyzed. Additionally, the effect of the use of those processes on the text and any particular challenges that ELLs may encounter when encountering these processes will be addressed. The following key will aid the reader as findings are presented.

Graph 1. Results of genre analysis

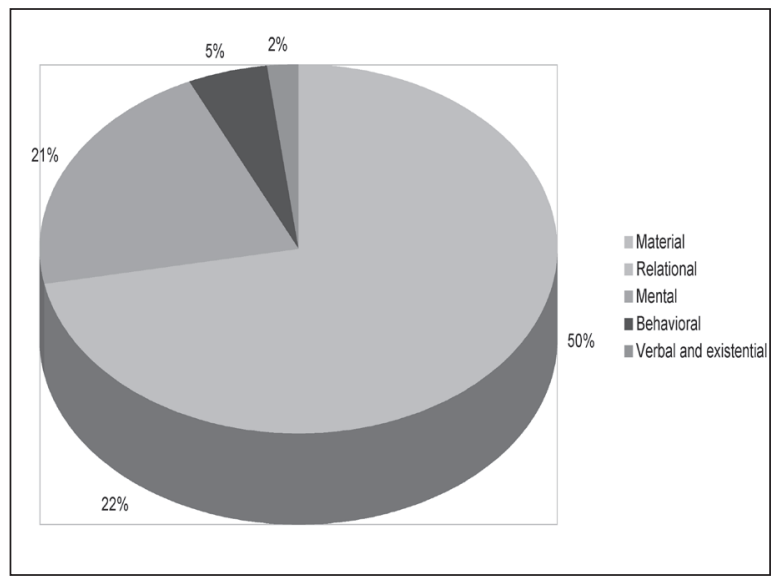

\section{Key to Text Source}

Texts 1 and 2- Massachusetts Comprehensive Assessment (MCAS) Preparation Materials

Text 3: MCAS RELEASED TEST

Text 4 and $5=$ Texas Knowledge Assessment System (TKAS) Preparation Guide

Text 6: TKAS Released TEST $5^{\text {th }}$ grade

\section{Use of Material Processes}

Results of the genre analysis reveal that material processes comprise the largest number of processes appearing across the genre. Material processes help construct the outer or visible experiences that happen in the world in contrast to the inner less visible experiences that constitute mental processes (Halliday and Matthiessen, 2004). In the following section, I provide examples of these material processes as they appear in the texts and analyze their contribution to the overall construction of meaning and particular textual effects of their inclusion. Table 3 provides samples of material processes as used in each of the texts: 


\section{Material Processes}

Text 1: Tornados

When the warm wet air crashes into the colder air, a tornado forms.

The currents of air swirl as they rub and twist together

Text 2: Things that Fall From the Sky As asteroids move around the sun, they sometimes crash into each other.

If they enter our atmosphere, gravity pulls them towards Earth.

Text 3: Diggin' Dirt

When plants and animals die, organisms feed on them, releasing their chemicals and energy into the soil for use by future generations

Text 4: The Mystery of the Moving Rocks

The rocks themselves leave behind signs of their travels.

Text 5: Planet Facts

The thick clouds that cover Venus make the heat on the planet intense.

Text 6: Emperors of the Antarctic A large male emperor penguin waddles slowly across the ice to the water. He dives deep into the chilly salt water and then springs back onto the ice.

While material processes appear in each of the texts, the analysis reveals that they appear with the greatest frequency in text 1 , Tornados of which they comprise $81 \%$ of the total processes used (26 of 32). A total of 38\% (12/32) of the material processes found in this text are material processes describing movement. The use of material processes of movement like "swirl" and "move" and "twist" represents a linguistic choice that affects the text in that it creates a descriptive image of the tornado's movement. The author's inclusion of additional material processes such as "picks up", "moves", "meets", "crashes" and "forms" functions to reinforce this image and emphasizes the active and potentially destructive nature of the hurricane. Text 4, The Mystery of the Moving Rock, also relies primarily on the use of material processes (28/53 or $53 \%$ ). Of these material processes, 46\% (13/28) are material processes of movement. Since the purpose of the text is to describe the movement of rocks, the author's use of a large number of material processes of movement, as in the tornado text, remains both logical and effective as it contributes to this movement imagery.

Text 3, Diggin` Dirt, which describes the properties of dirt, also uses a large number of material processes (53\%), however, in contrast to Texts 1 and 4, does not use a large number of material processes of movement (only $12 \%$ of all the material processes). Rather, the material processes appearing in this passage place emphasis on the properties of dirt as in "Dirt holds the roots of plants and supplies them with nutrients, so the plants can grow." In this text, material processes of movement only appear when the author describes the formation of dirt through the decomposition of rocks. To do so, the author chooses material processes of movement such as "breaks down," "contrasts" and "expands" functions to emphasize the progression involved in the rock's decomposition.

In Text 2, Things That Fall From the Sky, 45\% of the processes used are material, but as in Text 3 , the author employs fewer material processes of movement. When they do appear, they are located in a paragraph the context and purpose of which is the description of the transformation of meteorites to asteroids. Here the author employs material processes of movement, such as "move" (used 3 times in the paragraph), "crash", "break off," "enter," and "pulls.' The effect of the use of these particular material processes within this context is a reinforcement of the imagery of the movement accompanying the description of the asteroid's disintegration.

The preceding conclusions present a detailed linguistic analysis of the context of use and function of elements of material processes 
within informational texts. However, the question remains as to how this analysis actually benefits those concerned with language pedagogy and language research.

The implications for language research and pedagogy are many. The primary advantage of teaching ELLs how to recognize and use material processes is to aid and increase their comprehension of a text. Given that reading passages on standardized tests generally are accompanied by few or no actual visuals that could be used to scaffold their comprehension, ELLs can be taught to identify the material process so that they may more effectively visualize an image of what is happening in the text. Certainly, visualization is a proven comprehension improvement strategy for nearly all students, but to ELLs whose vocabulary is developing, placing an emphasis on these processes over other lexical elements may improve their visualization strategies and aid their text comprehension. For example, if a teacher were to scaffold ELLs instruction to emphasize these processes by having them visualize these actions and then draw the events that are unfolding in the text, a reasonable increase in comprehension could be expected.

The implications of teaching about material process use extend to writing pedagogy, as well. For instance, when writing or responding to test prompts that ask ELLs to describe scientific objects or occurrences, knowledge of how material processes function to create an image of movement for their audience can lead ELLs to employ these processes and in turn lead to more effective, image provoking responses. For instance, if they are writing to describe a hurricane or tornado, or to describe what they saw after mixing two chemicals, their choice of material processes of movement creates a clearer and more descriptive image of the action for their audience.
Lastly, critical pedagogical implications also exist. As students learn to take a more critical stance towards the texts with which they are engaging, ELLs familiar with the use of material processes can evaluate an author's choices of processes to determine how those processes reflect the author's stance. For instance, in the sample of lexically dense speech provided in Table 1, the word "Increases" represents a form of grammatical metaphor when used as a nominalization. The critical reader with knowledge of processes would recognize such a transformation, and in turn, question and perhaps challenge an author's motivation for choosing this nominalization.

\section{Relational Processes}

Relational processes appear with the second greatest level of frequency in the informational science texts examined here. Specifically, they comprise a total of $22 \%$ of the processes appearing across the texts. In more than half of the analyzed texts they comprised greater than $25 \%$ of the processes. In SFL terms, relational processes function to establish a relationship between two concepts. In the "Planets Facts" text (Text 5), the relational process served to identify or assign attributes to the participant, in this case a planet. The effect of this identity and attribute assignment is to define the topic of the reading and expand the reader's knowledge base about the topic, perhaps by relating the topic to the reader's background knowledge such as in the clause, "Venus and Earth are almost the same size." Assuming that ELLs have some existing knowledge base of the approximate size of earth, and given the information in this clause, they can relate the new information to their background knowledge and increase their comprehension. The following table illustrates identifying and attributive relational processes, labeled in bold, as they appear in the three texts. 


\section{Relational Processes: Identifiers}

Text 1: Tornados

A tornado is a powerful, swirling, funnel shaped cloud that sweeps across the land.

Warm air moving across the land is the first thing it

needs.

(This is why) a tornado is sometimes called a twister.

Text 2: Things That Fall From the Sky

These are called meteorites.

Asteroids are very small planets made up of dark rocky material.

Meteorites are chunks of space rock that reach earth's surface.

Text 3: Digging Dirt

Dirt is the home for countless organisms.

(Remember that) 75 percent of the earth's surface is water.

(Scientists estimate that only about) 10 percent of the earth's surface is covered with soil that is useful for farming.

Text 4: Mystery of the Moving Rocks

... strong winds might be the cause

Text 5: Planet Facts

The temperature on Venus is 900 degrees Fahrenheit.

Text 6: Emperors of the Antarctic

The Penguin Encounter is a great place to get a close look at some cool birds.

A new home for them seemed to be the perfect answer.

In these examples, the relational processes each function to identify a specific participant in relation to a more generalizable category. SFL analysts label the specific participant the value and the more generalizable category the token (Halliday and Matthiessen, 2004, Thompson, 2004). For example, in the clause "Asteroids are very small planets made up of dark rocky material" the participant, "Asteroids", serves as the value and "Very small planets made up of dark, rocky material" is the token. Values and tokens may appear either before or after the relational process, their location depending upon which element the author chooses to place in theme position (Halliday and Matthiessen, 2004).
This may seem insignificant and, in fact, in most cases that participant placement in the relational clause made little or no difference in the clause's effectiveness. However, for ELLs awareness of the function of the relational process comes into play when examining a text critically. The participants the author chooses to front and whether they are presented as values or token indicates which "wider ideological beliefs may be more open to question" (Thompson, 2004, pg. 98). The passage from Text 6 exemplifies this notion. Here, the "Penguin Encounter" is in the value position. The remainder of the clause is the Token and it reveals the author's belief that the Penguin Encounter is a good place to see birds. The critical reader may ask, "For whom is it a great place?" By placing "Penguin Encounter" in the Value position the author subtly advocates the appropriateness of this location as a venue for bird watching- in contrast to an arguably better place to see birds- their natural, unspoiled environment, which the text describes, incidentally, as having been lost to global warming. However, if the participant "Penguin Encounter" were to occupy the Token position the text would read- A great place to get a close look at some cool birds is the Penguin Encounter-a clause that arguably has a different effect on the reader. By placing emphasis on Penguin Encounter by choosing to locate it in the Value position, the reader is more likely to accept the premise of the sentence without interrogating the ideology undergirding the clause. Had the participants reversed positions, the reader would more likely expect such participants as "a swamp" or "river" to occupy the token position in contrast to the theme park, Penguin Encounter.

Awareness of how relational processes function help ELLs learn to question critically how the language is functioning and carrying the ideologies of the author who in this case seems to think there is nothing alarming about having to 
move penguins from their natural habitat to Sea World San Diego.

\section{Relational Processes-Attributive}

In addition to identifying relational processes, there are also many attributive relational processes in each of the texts as follows:

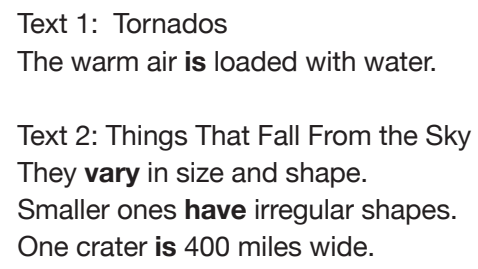

Text 5: Planet Facts

Venus and Earth are almost the same size.

Both planets have an atmosphere that is made up of a layer of gases that surround the planet.

Text 6: Emperors of the Antarctic First, it had to be cold, very cold, just like the Antarctic.

The Penguin Encounter is located at Sea World in San Diego, California. It is the home of several hundred penguins.

Attributive relational processes comprised between $15 \%$ and $25 \%$ of processes in the analyzed texts. Across the focal texts, attributive relational processes systematically describe participants and provide detailed information to create a clearer picture of the participants for the reader, such as "They vary in size and shape." ELLs developing an awareness of the genre should recognize that attributive relational processes function to assess or assign an opinion to a participant.

\section{Mental Processes}

Mental processes represent "the internal world of the mind" and refer to such internal mental actions such as "thinking, imagining, wanting, liking, seeing, etc" (Thompson, 2004, pp. 92). They fall into four categories: emotion, cognition, perception, and desideration (Thompson, 2004). Analysis of the texts revealed that mental processes made up approximately $21 \%$ of all the processes. Text 4, "The Mystery of the Moving Rocks" contained the largest number of mental processes at 30\% and Text 5, "Planet Facts" contained the least. I provide some examples of how mental processes are used across the texts.

Text 1: Tornados

Can you guess the direction the colder air comes from?

Text 2: Things That Fall From the Sky

Have you ever seen a shooting star?

That's the light you see.

Text 3: Diggin' Dirt

But if you've ever felt cozy mud squishing between your toes or planted seeds in soil and watched them bloom into beautiful flowers, you know that dirt is amazing stuff!

Text 4: Mystery of the Moving Rocks Some scientists think that heavy rains and strong winds might be the cause. The scientists guess that strong winds may be able to push rocks across that slippery ground after a rainstorm.

Text 5: Planet Facts

From the surface of Venus, the sky would look orange rather than the blue of Earth's sky.

Text 6: Emperors of the Antarctic Scientists fear that this drastic change in the environment could destroy many of the emperor's nesting areas.

Because of the changes in the environment, scientists are concerned about the future of the emperor's home.

Analysis reveals that the location of the appearance of these particular processes affects their function. For instance, the examples from Texts 2 and 3 each come from the first paragraph of their respective texts. The clauses placed at the beginning of a text contain a larger number 
of mental processes of perception (Have seen, see, felt, squishing,). The effect of this initial use of mental processes is the establishment of a connection with readers through the activation of their background knowledge and an appeal to their senses and experiences. The behavioral process, "watched", also appearing in the initial paragraph, has a similar effect as it reminds readers of their past experience with the subject of the text. ${ }^{1}$

The use of mental processes to establish a connection with the reader is not always employed at the beginning of the text, however. For instance, the example from Text 1 in which the reader is asked to "guess", is located in the middle of the text's passage. The result of the use of this cognitive mental process is twofold. First, as it appears half-way through the text, and represents a "demand" for information ${ }^{2}$, it functions to engage the reader and maintain the readers' attention. Secondly, it prompts readers to continue activating their background knowledge about the subject to make a connection with the text and thus, scaffolding their comprehension.

Analysis of the mental processes in the text found that the participant most associated with cognitive mental processes was the scientist. Throughout the texts the participant "scientist" was most often paired with cognitive mental processes, such as "Scientists think" (Texts 4 ) or "Scientists have deduced" (Text 6) or "Scientists estimate" (Text 3). As a matter of fact, in Text 6 , scientists were matched with a mental process at total of six times and in Text 4 a total of five times. This pairing of the participant "scientist" with a mental process results in the scientist being portrayed as a thinker rather than a doer. Across the texts, scientists are portrayed as producers of mental knowledge who "think about," "know,"

1. The processes "watched" is an example of a behavioral processes in that it represents a conscious action in contrast to the perceptional process "see."

2. In SFL, language falls into two categories: either a demand for or supply of information. "believe, " "don't believe," deduce," "estimate," "remain baffled" or "explore" whatever serves as the science topic. Their inclusion provides authority and gives credence to the text.

It is important to note that none of the texts identify any scientist by name. In fact, the closest a text comes to identifying the scientist is in Text 6 (Emperors of the Antarctic), and in that text the scientist is identified by his first name only (Todd). For ELLs to take a critical stance, they need to learn to question why the participants are not named, who they are exactly, and for whose interests they participate. Without taking a critical look at mental processes, the motives of nameless scientists whose affiliations and sources of support are not identified remain unquestioned and leave ELLs less equipped to challenge the authority of text.

\section{Conclusions}

SFL analysis of these test preparation materials and excerpts reveals much about how language is used across the texts. The analysis reveals that verbal and behavioral processes appeared infrequently across the informational texts. However, in contrast, material processes appear recurrently (close to 50\%) and many of these material processes emphasize movement. As explained above, these processes of movement may contribute to ELLs' comprehension by helping them visualize actions in the text. For example, if ELLs were reading about a tornado on their ELA assessments, and they paid specific attention to the material processes, they may better visualize an image of the tornado's movement and improve their comprehension of the text.

SFL analysis also reveals that mental processes appear across the genre samples. Close analysis of the ideational metafunction brings attention to how mental processes function to help readers make connections with the text. These 
connections help students maintain focus on the topic as they read depending on their location within the text activate background knowledge to aid comprehension. However, mental processes can also be paired with specific participants to bring a sense of authority to the text, as evidenced by the pairing of scientists with a variety of mental processes. If ELL educators make these choices visible to their learners, their students may pay closer attention to the use of mental processes and be better positioned to question the authority these pairings add to the text. How these conclusions can be applied to second language education is outlined below.

\section{Implications for Education}

The intent of this research was to use SFL as a tool to reveal how language functions in the genre of informational texts as found on test preparation materials and how genre expectations are in turn established. Calling attention to the role of the ideational metafunction explicitly increases the genre awareness of language researchers, teachers, and educators which has both pedagogical and social applications in language education. First, those involved in curriculum development may design materials which seek to bridge the gap in ELLs' academic literacy development by showing the ways the genre constructs meaning linguistically. From a sociopolitical standpoint, increased genre awareness allows students to take a more informed critical stance and viewpoint when engaging with informational texts. ELLs will be able to see how the text employs various linguistic elements to position them as readers and establish a world view through the presentation of information within the text.

Educational researchers interested in the connection between critical pedagogy and genre studies in linguistically and culturally diverse classrooms will find that as a method of linguistic analysis, and as a tool for critical discourse analysis, SFL serves to make visible the political aspects surrounding language and helps to uncover language's contribution to the reproduction of socially dominant ideologies. Language teacher educators will also find that the development of genre awareness is essential for writing teachers, especially those who teach English language learners, as they must be explicit about the generic expectations student writers encounter. It is not to say that students should mindlessly and uncritically learn to utilize formulaic genre templates and their related features, rather, linguistically diverse students benefit from knowing these linguistic features evident in the target genre. Instruction that makes visible these language functions may lead to increased generic awareness which allows ELLs to become skilled at engaging with the genres prevalent in academic literacy. With a heightened sense of genre awareness, ELLs remain more adequately positioned to challenge these generic expectations and examine them critically to see how participants, including themselves, are positioned in texts, and how power manifests itself through language.

For ELLs, drawing on SFL prepares them to take a critical standpoint by providing them the tools they need to "uncover the linguistic technologies used by affectedly depersonalized genres, such as informational reports" so that they may see how the language of informational reports "embodies ideologies" (Cope and Kalantzis, 1993, pp. 85) and positions them as readers and writers. Close linguistic examination of texts using SFL makes visible the ideologies in the genre. For instance, the author of one of the texts analyzed here, who, as in all the texts remains nameless, positions the nominalized participant "Increases" as the agent responsible for global warming. The author's choice to use a non-human participant omits human culpability from the text. That is 
to say, humans do not cause global warming, rather, "Increases" do. Therefore equipping ELLs with the ability to recognize language functions and ensuring that ESL educators have the metalinguistic knowledge necessary to teach these functions, allows ELLs to analyze discourse such as this example in a critical manner.

\section{Further Research Directions}

The research presented here is limited in scope to the realization of one metafunction as it appears within informational texts found on test preparation materials and on one actual test. In an era of high stakes tests, however, many states turn to materials such as the ones examined here to help their ELLs. An in depth linguistic analysis contributes to understanding how this genre functions and gives educators greater knowledge about how they can help their ELLs engage successfully with these texts.

This research should not end here. Further research calls for comparative generic analysis of other states' test preparation materials to see to what extent the generic structure of informational texts appears across these materials and within their tests. Research in this area can help language educators prepare their linguistically diverse students to achieve success on high stakes exams by improving their ability to comprehend the material that is preparing them for such exams.

Knapp and Watkins (2005) claim that informational reports follow "formalized" and "systematically described" generic patterns, and the ones analyzed here seem to fit that generic category. However, further analysis of other state's test materials may show the extent to which these formalized descriptions adhere to generic structure so that educators working with ELLs may make visible the generic expectations to ensure successful performance on these exams.

Another step is to compare the test preparation materials to the science and social studies texts students use in class and the informational texts they are and will be expected to use in out-of school contexts to determine the extent of congruency existing between the generic structures and conventions of the texts. Evaluating the extent to which the genres form a continuum remains important. Since students are expected to perform well on tests, it would only be pedagogically sound that the texts used in class reflected language found on the test materials. If the tests are intended to predict how students will perform upon academic exit, then a correspondence between the generic structures of classroom texts, test preparation texts, and out of school informational texts would be beneficial. These are important issues for ensuring that all students learn to construct the practices of the informational text genre found in academic texts and learn to successfully engage with academic literacy.

\section{References}

Brice Health, S. (1982) What no bedtime story means: Narrative skills at home and school. Language and Society, 11, 49-76.

Brice Health, S. (1986) Ways with words: Language, life, and work in communities and classrooms. New York: Cambridge University Press.

Cope, B. \& Kalantzis, M. (eds.) (1993) The powers of literacy: a genre approach to teaching writing. Pittsburg: University of Pittsburg Press.

Christie, F. (1995) Pedagogic discourse in the primary school. Linguistics and education, 7, 221-243.

Christie, F. (1997) Learning the literacies of primary and secondary schooling. In Literacy and schooling (4679). London: Routledge.

Coffin, C. (1997) Constructing and giving value to the past. In F. Christie and J.R. Martin (eds) Genre and institutions: social processes in the workplace and school. London: Continuum.

Derewianka, B. (1990) Exploring how texts work. Newtown, New South Wales, Australia: Primary English Teaching Association. 
Testing: A Systemic Functional View of High Stakes Test Preparation Materials

Fang, Z. (2004) Scientific literacy: a systemic functional linguistics perspective. Wiley Interscience (www. wileyinterscience.com) retrieved August 2, 2007)

Fang, Z. (2006) The language demands of science reading in middle school. International Journal of Science Education, 28 (5), 491-520.

Gebhard, M., Habana Hafner, A. \& Wright, M. (2004) Teaching language learners the language game of math. In Michael Sadowski (Ed.) Teaching immigrant and second language students: strategies for success (pp. 33-46). Cambridge, Ma: Harvard Educational Publishing Group.

Gebhard, M., Harman, R. , \& Seeger, W. (2007) Reclaiming Recess: learning thelanguage of persuasion. Language Arts, 84 (5), 419-430.

Gee, J. (1990) Social linguistics and literacies: ideologies in discourses. London: Falmer.

Halliday, M. (1978) Language as social semiotic: the social interpretation of language and meaning. London: Edward Arnold.

Halliday, M. \& Matthiessen, C. (2004) An introduction to functional grammar. London:Hodder Arnold.

Kohn, A. (2000) The case against standardized testing: raising the scores, ruining the schools. Portsmouth, $\mathrm{NH}$ : Heinemann.

Knapp, P. \& Watkins, M. (2005) Genre, text, grammar: technologies for teaching and assessing writing. UNSW Press.

Kress, G., Jewitt, C., Ogborn, J., \& Tsatsarelis, C. (2001) Multimodal teaching and learning: the rhetorics of the science classroom. London: Continuum.

Lemke, J. (1990) Talking Science: Language, learning and values. Norwood, NJ: Ablex.

Lipman, P. (2004) High stakes education: inequality, globalization, and urban school reform. New York: Routledge Falmer.

Martin, J.R. (1993) Genre and literacy: modeling contexts in educational linguistics. Annual review of applied linguistics 13, 141-72.
Review, Practice, and Mastery of Massachusetts English Language Arts Curriculum Framework (2007) lowa: Perfection Learning Corporation.

Schleppegrell, M. (2004) The language of schooling: a functional linguistics perspective. Mahwah, $\mathrm{NJ}$ : Lawrence Erlbaum.

Schleppegrell, M. (2006) The challenges of academic language in school subjects. In I. Lindberg \& K. Sandwall (Eds.), Spraket och kunskapen: att lara pa sitt andrasprak I skola och hogskola (pp. 47-69). Goteborg: Sweden: Gotesborg universitet institutet for swenska som andrasprak.

Schleppegrell, M. (2007) The linguistic challenges of mathematics teaching and learning: a research review. Reading and writing quarterly, 23, 139-159.

Schleppegrell, M., Achugar, M., \& Oteiza, T. (2004) The grammar of history: enhancing content-based instruction through functional focus on language. TESOL QUARTERLY, 38 (1), 67-93.

Schleppegrell, M., \& Go, A. (2007) Analyzing the writing of English learners: a functional approach. Language arts, 84 (6), 529-538.

Schulze, J. and Ramirez, J. (2007) Intertextuality as resource for building ELLs generic competence: a systemic functional view. Colombian Applied Linguistics Journal, 9, 69-98.

Thompson, G. (2004) Introducing functional grammar. London: Arnold.

Veel, R. (1997) Learning how to mean-scientifically speaking: apprenticeship into scientific discourse in the secondary school in F. Christie and J.R. Martin (Eds.) Genre and institutions: social process in the workplace and school. London: Continuum.

Veel, R. (1999) Language, knowledge, and authority in school mathematics. In F. Christie (Ed.) Pedagogy and the shaping of consciousness: Linguistic and social processes (pg. 185-216). London: Continuum. 
Appendix 1: Genre Analysis Worksheet

SFL ANALYSIS OF HIGH STAKES TEST PREP MATERIALS: Ideational Metafunction

STATE

\section{PROCESSES}

\begin{tabular}{|c|c|c|c|c|}
\hline $\begin{array}{c}\text { Mental } \\
\text { (emotion, cognition, } \\
\text { perception, desideration) }\end{array}$ & Material & $\begin{array}{c}\text { Relational } \\
\text { (attributive, } \\
\text { identifier) }\end{array}$ & Behavioral & Verbal \\
\hline & & & & \\
\hline
\end{tabular}

State

PARTICIPANTS

\begin{tabular}{|l|l|l|l|l|}
\hline Senser & Actor, Goal & Carrier, Token & Behaver & Sayer, Receiver \\
\hline & & & & \\
\hline
\end{tabular}

State

\section{CIRCUMSTANCES}

\begin{tabular}{|l|l|l|l|l|l|l|}
\hline $\begin{array}{l}\text { Location } \\
\text { (Place, } \\
\text { Time) }\end{array}$ & $\begin{array}{l}\text { Manner } \\
\text { (quality, means, } \\
\text { comparison) }\end{array}$ & Reason & Purpose & Behalf & $\begin{array}{l}\text { Contingency } \\
\text { (Condition, } \\
\text { Concession) }\end{array}$ & $\begin{array}{l}\text { Accompaniment } \\
\text { (With what, with } \\
\text { whom, product-what } \\
\text { into?) Matter Angle }\end{array}$ \\
\hline & & & & & & \\
\hline
\end{tabular}

